\title{
Kenny-Caffey syndrome is part of the CATCH 22 haploinsufficiency cluster
}

\author{
M A Sabry, M Zaki, S J Abul Hassan, D G Ramadan, M A Abdel Rasool, S A Al Awadi, \\ Q Al Saleh
}

\begin{abstract}
We report four sibs with Kenny-Caffey syndrome in a consanguineous Bedouin family. The first two died in the neonatal period while the remaining affected brother and sister had all the characteristic clinical, biochemical, and radiological abnormalities of the syndrome. These included severe pre- and postnatal growth retardation, cortical thickening of the tubular bones with medullary stenosis, eye abnormalities, facial dysmorphism, hypocalcaemia, and low levels of parathyroid hormone. The children also showed intracranial calcification, impaired neutrophil phagocytosis, increased proportion of $B$ lymphocytes, reduced CD4 and CD8 subpopulations of T lymphocytes, and inhibited transformation in response to Candida antigen. Fluorescence in situ hybridisation (FISH) was applied to blood lymphocyte metaphase spreads from these two Bedouin sibs and their parents using probe D22S75 (Oncor), specific for the DiGeorge critical region on chromosome 22q11.2. The presence of 22q11.2 haploinsufficiency was identified in the affected sibs, which was transmitted from the phenotypically normal mother. The present report widens the spectrum of CATCH 22 microdeletion to accommodate Kenny-Caffey syndrome. (F Med Genet 1998;35:31-36)
\end{abstract}

Keywords: Kenny-Caffey syndrome; CATCH 22; 22q11.2 haploinsufficiency cluster

Kuwait Medical Genetics Centre, Kuwait

M A Sabry

S J Abul Hassan

M A Abdel Rasool

S A Al Awadi

Paediatric

Department,

Farwaniya Hospital,

Kuwait

M Zaki

Q Al Saleh

Paediatric

Department, Sabah

Hospital, Kuwait

D G Ramadan

Correspondence to:

Dr Sabry, 4 Channel Close,

Rhoose, Vale of Glamorgan B62 3EH, UK.

Received 7 March 1997 Revised version accepted for publication 21 July 1997 with schizophrenia in some cases. ${ }^{4}$ Other members of the CATCH 22 group include the conotruncal anomaly-face syndrome (MIM 217095), ${ }^{5}$ which comprises a variety of cardiac outflow tract defects, the Caylar cardiofacial syndrome with unilateral facial palsy owing to hypoplasia of the depressor anguli oris muscle associated with congenital heart disease, ${ }^{6}$ and the Opitz BBBG syndrome (MIM 145410) with its distinctive oesophageal abnormalities, dysphagia, hypertelorism, and hypospadias.

Kenny-Caffey syndrome (MIM 127000, 244460 ) is another rare disorder of which approximately 26 cases have been published. It is characterised by severe pre- and postnatal growth retardation, small, slender long bones with medullary stenosis, poorly ossified skull bones, delayed closure of the anterior fontanelle, and early onset episodic tetany. Important eye signs in Kenny-Caffey syndrome include microphthalmia, corneal opacity, myopia/hyperopia, optic atrophy, macular clouding, papilloedema/pseudopapilloedema, calcium deposition in the cornea and retina, and tortuous retinal vessels. Other traits with variable presentation in the syndrome are hypoplasic nails and neonatal liver disease. Laboratory defects in Kenny-Caffey syndrome include the presence of low serum calcium and magnesium, high serum phosphorus, neonatal hypoparathyroidism, sometimes with anaemia, eosinophilia, and persistent neutropenia. The immunological defect in Kenny-Caffey syndrome is not consistent with DiGeorge syndrome and is characterised by the presence of a specific $T$ cell abnormality in terms of increased suppressor fraction CD8 with a consequent low helper/suppressor ratio, in addition to reduced $\mathrm{T}$ cell response to mitogens.

So far, there is no consensus on the mode of inheritance of Kenny-Caffey syndrome. Some cases have been described in which sporadic/ autosomal dominant or recessive patterns were suggested..$^{711}$ Based on our clinical experience with Kenny-Caffey syndrome, coupled with reviewing medical publications on the disease, we noted its phenotypic overlap with DiGeorge syndrome in which hemizygous 22q11.2 microdeletion has been identified in most patients. $^{212}$ This has prompted us to explore the possibility that, like members of the CATCH 22 family, Kenny-Caffey syndrome might be associated with a deletion within 22q11.2. This report describes, for the first time, the identification of maternally inherited 22q11.2 haploinsuffiency in sibs with KennyCaffey syndrome. The implications of this finding are critically discussed. An abstract of 


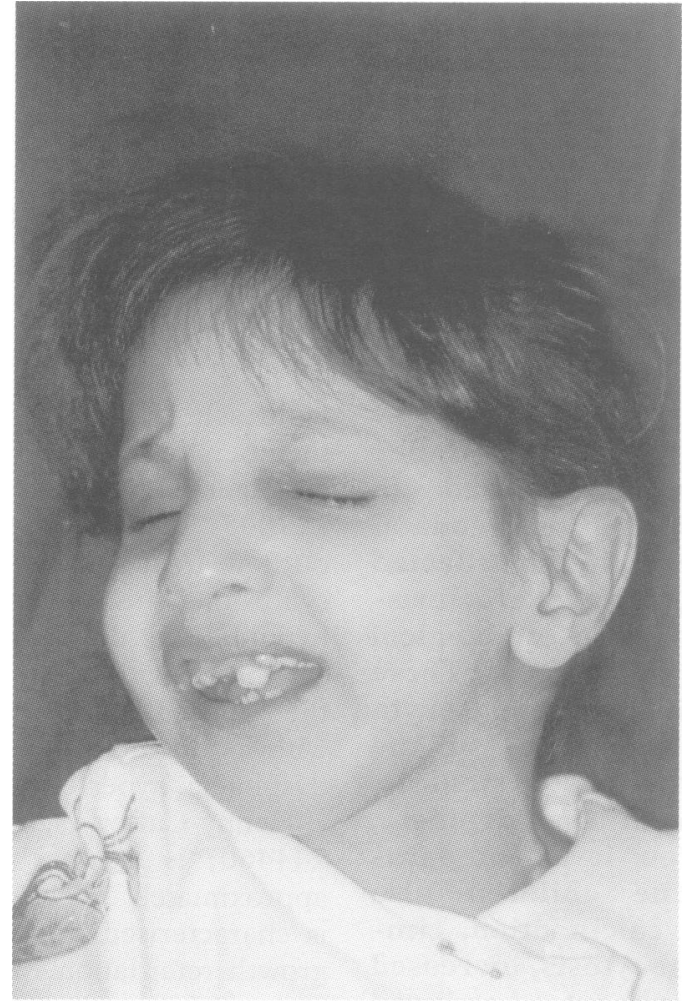

Figure 1 Case 1 showing characteristic facial features with deep set, small eyes, low set ears, micrognathia, and irregular, carious teeth. (All photographs reproduced with permission.)

this work has been communicated to the 29th Annual Meeting of the European Society of Human Genetics. ${ }^{13}$

\section{Case reports}

CASE 1

This girl was born at term in January 1988 to first cousin, healthy, Bedouin parents. Birth weight was $2250 \mathrm{~g}(<-2 \mathrm{SD})$. The parents had five healthy daughters, two healthy sons, an affected son (case 2), two affected daughters who had died (cases 3 and 4), and a stillborn boy. Case 1 was ascertained at the age of 11 days because of repeated convulsions with low serum levels of parathyroid hormone (1.1 $\mathrm{pmol} / \mathrm{l}$, reference range 1.3-7.6), calcium (1.57 $\mathrm{mmol} / \mathrm{l}$, reference range $2.2-2.62$ ), and magnesium ( $0.45 \mathrm{mmol} / \mathrm{l}$, reference range $0.74-0.99)$, while serum phosphate was high $(4.2 \mathrm{mmol} / \mathrm{l}$, reference range 0.81-1.58) and serum alkaline phosphatase was $203 \mathrm{U} / 1$ (reference range 50-136). Chest $x$ ray showed a normal thymic shadow. She was given vitamin $\mathrm{D}$ and calcium supplementation with subsequent correction of her biochemical abnormalities and temporary cessation of the hypocalcaemic seizures which recurred at 8 months, at which time her growth parameters were low for her age (weight $5700 \mathrm{~g}$ (<-3 SD) and length $57 \mathrm{~cm}(-5 \mathrm{SD}))$. The anterior fontanelle was $1.5 \times 2 \mathrm{~cm}$. She was found to have frontal bossing, microphthalmia, micrognathia (fig 1), short extremities, and small hands and feet. The cardiovascular system did not show any abnormality and she had good head control, but was unable to sit even with support. Investigations at the age of 8 months showed that serum calcium was 1.58 $\mathrm{mmol} / \mathrm{l}$, phosphorus $2.98 \mathrm{mmol} / \mathrm{l}$, magnesium

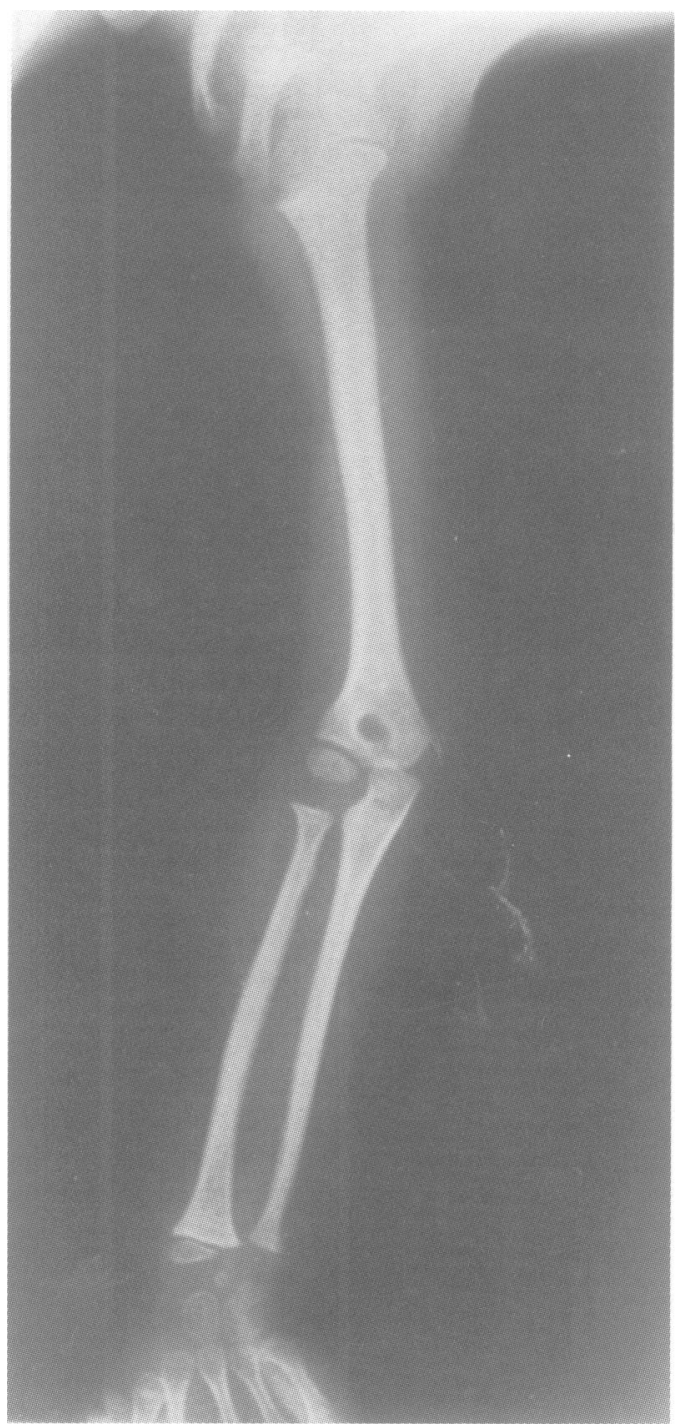

Figure $2 X$ ray of case 1 showing cortical thickening and medullary stenosis of the long bones of the upper limb.

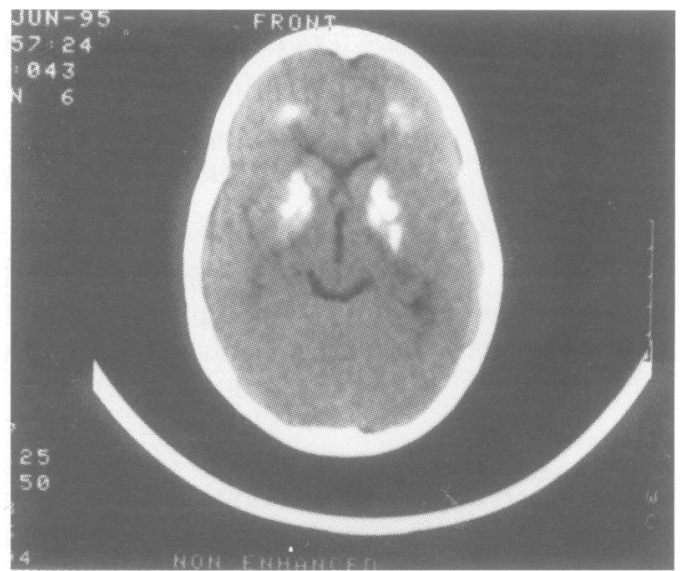

Figure 3 Non-enhanced CT scan of the head of case 1 showing intracranial calcification of the frontal lobes and basal ganglia.

$0.6 \mathrm{mmol} / \mathrm{l}$, and alkaline phosphatase $224 \mathrm{U} / \mathrm{l}$. The mother had normal serum levels of calcium, phosphorus, magnesium, and alkaline phosphatase. Skeletal survey of the girl showed medullary stenosis of the tubular bones with cortical thickening (fig 2) and absence of diploetic space in the cranial bones. The girl had several hospital admissions because of repeated bacterial infections (pneumonia, 

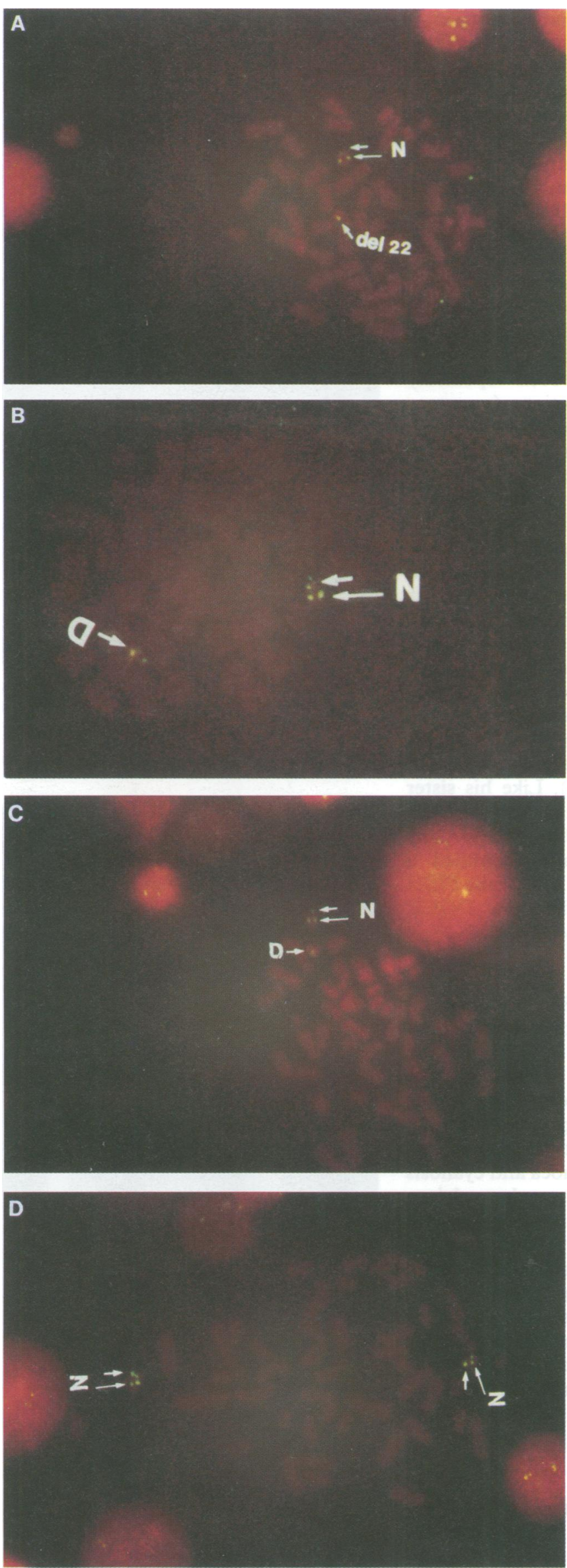

Figure 4 Fluorescence in situ hybridisation (FISH) of peripheral blood lymphocyte metaphase spreads from the two sibs with Kenny-Caffey syndrome (cases 1 and 2) and their parents. $N$ denotes the non-deleted chromosome $22 . D$ or del 22 denote chromosome 22 with $22 q 11.2$ microdeletion. $(A),(B),(C)$, and $(D)$ represent case 1, case 2, the phenotypically normal mother with the microdeletion, and the unaffected father, respectively. meningitis, septicaemia, UTI, and chronic otitis media with Pseudomonas and $S$ aureus). Immunological testing showed normal serum immunoglobulin and complement profiles, reduction of both $\mathrm{CD} 4$ and $\mathrm{CD} 8$ subpopulations of $T$ lymphocytes, and increased proportion of B lymphocytes. Transformation in response to Candida antigen was reduced and there was impaired phagocytosis of $S$ aureus by the patient's neutrophils in autologous serum. At the age of 6 years, she started to have recurrent corneal ulceration which was complicated by corneal opacities. Head CT scan at the age of 7 years showed symmetrical calcifications of the basal ganglia and frontal lobes (fig 3). She continued to grow poorly so that at 8 years her weight was $8.7 \mathrm{~kg}$, height 87 $\mathrm{cm}$, and head circumference (OFC) $42 \mathrm{~cm}$, while her psychomotor development was severely retarded. By that time, her teeth were markedly decayed and maloccluded. Up to the present time, she is still dependent on 1-alpha vitamin $\mathrm{D}$, calcium, and magnesium supplementation.

Conventional cytogenetic techniques with high resolution banding failed to detect any abnormality in the chromosome constitution of the two Bedouin sibs (cases 1 and 2) or in their parents. Fluorescence in situ hybridisation (FISH) was then applied to blood lymphocyte metaphase spreads from the affected cases, their parents, and from normal control samples. Probe D22S75 (Oncor), specific to the DiGeorge critical region (DGCR) on chromosome 22q11.2, was used along with chromosome 22q13.3 control probe D22S39 (Oncor), according to the method described by the manufacturer. From each person investigated, 20 metaphases were examined. A signal of the control probe was detected on each of the chromosome 22 pair in metaphase spreads of all persons investigated. DGCR specific probe stained the two copies of chromosome 22 of normal control samples and of the father of the index cases. The same probe detected a signal on only one of the chromosome 22 pair from the affected subjects and their mother, thus indicating the presence of a maternally inherited 22q11.2 hemizygous microdeletion in the sibs with Kenny-Caffey syndrome (fig 4). The mother was phenotypically normal, both clinically and biochemically.

CASE 2

This boy was born at term in July 1995 by LSCS because of fetal distress. Apgar scores were 4 and 8 at five and 10 minutes respectively. Birth weight was $2500 \mathrm{~g}$, length 43 $\mathrm{cm}$, and OFC $32 \mathrm{~cm}$. He was found to have bilateral microphthalmia and corneal opacities (fig 5). He was kept in an incubator because of cyanosis and respiratory distress because of meconium aspiration. Initial biochemical investigations were normal, including serum calcium $(2.2 \mathrm{mmol} / \mathrm{l})$ and phosphorus (1.82 $\mathrm{mmol} / \mathrm{l})$. At the age of 4 days, however, routine blood testing showed a serum calcium of 1.7 $\mathrm{mmol} / \mathrm{l}$, albumin $28 \mathrm{~g} / \mathrm{l}$, phosphorus 1.62 $\mathrm{mmol} / \mathrm{l}$, magnesium $0.58 \mathrm{mmol} / \mathrm{l}$, and alkaline phosphatase $348 \mathrm{U} / 1$. These abnormalities 
were reversed initially by the adminstration of intravenous calcium and magnesium and later by calcium and vitamin $\mathrm{D}$ supplementation and the baby was discharged on day 15 postnatally. Two months later, he was readmitted with hypocalcaemic seizures and laboratory investigations again showed low serum calcium (1.32 $\mathrm{mmol} / \mathrm{l})$, magnesium $(0.56 \mathrm{mmol} / \mathrm{l})$, and parathyroid hormone $(0.9 \mathrm{pmol} / \mathrm{l})$, a high serum phosphorus (3.86 $\mathrm{mmol} / \mathrm{l})$, while alkaline phosphatase level was $245 \mathrm{U} / 1$. After correction of these biochemical abnormalities with intravenous calcium and magnesium, oral therapy with calcium, magnesium, and vitamin D (1-alpha drops) was instituted. Over the past one and half years, he has been repeatedly admitted with recurrent infections (pneumonia, gastroenteritis, UTI, and otitis media). Immunological investigations showed similar abnormalities to those detected in his sister (case 1). Head CT scan at the age of 10 months did not show any intracranial calcifications. Skeletal survey showed medullary stenosis of the long tubular bones (fig 6). He was last seen at the age of 18 months when his weight was $3800 \mathrm{~g}$, length $57 \mathrm{~cm}$, and OFC $40 \mathrm{~cm}$, all well below the 3 rd centile for age. There was marked psychomotor retardation with poor hand function and an inability to say any meaningful words or sit unaided. In addition, he had delayed dental eruption. Since then, his blood chemistry is being maintained on the previous therapy (see case 1). Like his sister (case 1), conventional cytogenetic techniques and high resolution banding did not detect any chromosomal abnormality and identified a normal male constitution $(46, X Y)$, while FISH analysis identified haploinsuffiency at DGCR (22q11.2), as mentioned above (fig 4).

CASE 3

Case 3 was a female born at 38 weeks' gestation in November 1984 with a birth weight of 2210 $\mathrm{g}$, length of $42 \mathrm{~cm}$, and OFC of $30.7 \mathrm{~cm}$. She was incubated because of being small for gestational age and having some dysmorphic features and right corneal opacity. On day 6 postnatally, she developed twitching of the facial muscles followed by apnoea and cyanosis with fisting. Investigations showed a calcium level of $4.6 \mathrm{mg}$, phosphorus $12.9 \mathrm{mg}$, and magnesium $1.3 \mathrm{mg}$, alkaline phosphatase 213 $\mathrm{U} / 1$ and parathyroid hormone $<1.5 \mathrm{mmol} / \mathrm{l}$. Other investigations, including complete blood count, blood cultures, CSF analysis, TORCH, and VDRL, were normal/negative. Chest $x$ ray was normal. Treatment consisted of antibiotics, calcium gluconate, magnesium sulphate, and vitamin $\mathrm{D}$. She died at 55 days following an apnoeic attack.

\section{CASE 4}

Case 4 was a female born at term in February 1986 with a birth weight of $2500 \mathrm{~g}$. She was incubated because of respiratory distress and was noted to have some abnormal facial features with microcephaly, microphthalmia, bilateral central corneal opacities, and bilateral anterior polar cataract. Chest $x$ ray showed pulmonary infiltration of the right middle zone

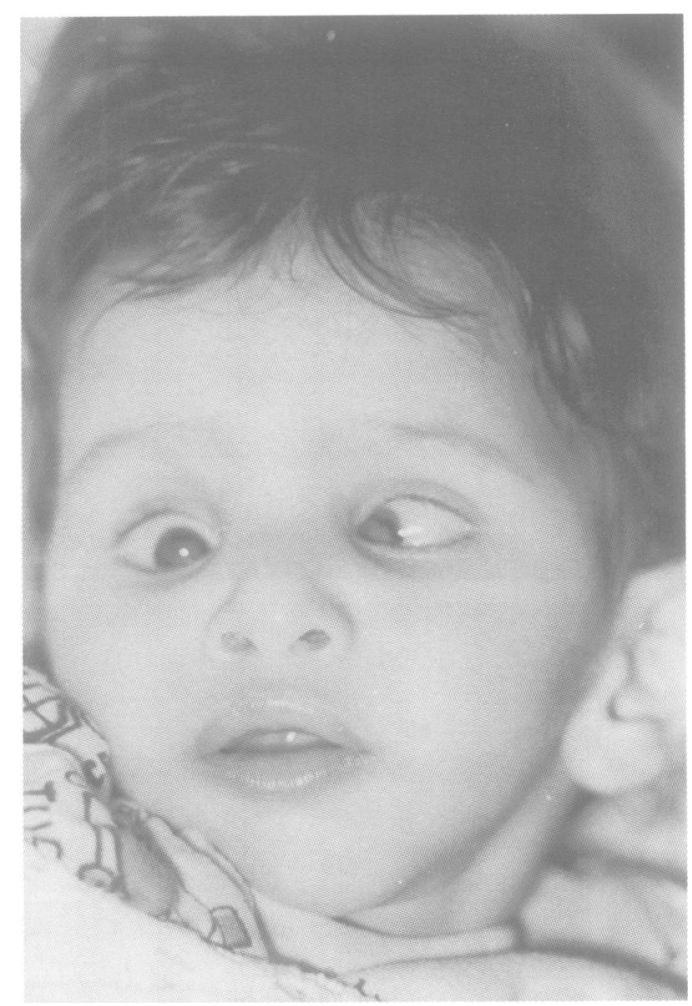

Figure 5 Photograph of case 2 showing the characteristic facial features: small, deep set eyes, squint, corneal opacities, low set ears, and micrognathia.

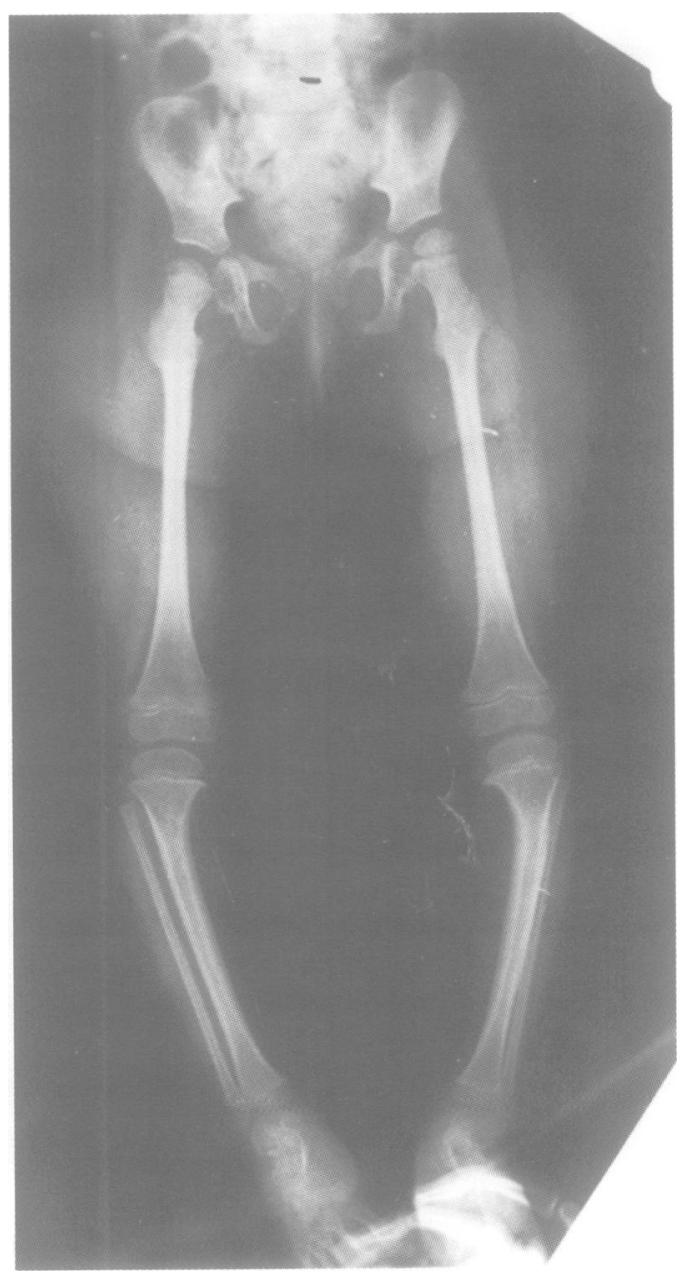

Figure 6 Skeletal survey of case 2 showing medullary stenosis of the tubular bones of the lower limbs. 
and appropriate care and antibiotic therapy were administered. At the age of 8 days she developed generalised convulsions. At that time, investigations showed haemoglobin of $11.3 \mathrm{~g} / \mathrm{dl}$, total WBC of $20 \times 10 / 1$ (polymorphonuclear cells $66 \%$, lymphocytes $32 \%$ ), and platelet count of $184 \times 10 / 1$. Blood culture grew coagulase negative Staphylococcus. Lumbar puncture was refused by the parents. Serum calcium was $1.82 \mathrm{mmol} / \mathrm{l}$, phosphorus 1.54 $\mathrm{mmol} / \mathrm{l}$, magnesium $0.59 \mathrm{mmol} / \mathrm{l}$, and alkaline phosphatase $213 \mathrm{U} / 1$. Parathormone level was not investigated. She was given intravenous calcium and magnesium with normalisation of the abnormal biochemical values. Her condition progressively worsened with the development of recurrent apnoeic episodes and she died at the age of 18 days.

\section{Discussion}

We report here a Bedouin family in which four sibs fulfilled the criteria for the diagnosis of Kenny-Caffey syndrome. The most consistent documented findings in Kenny-Caffey syndrome include characteristic radiological changes with cortical thickening and medullary stenosis of the long bones (in $96.2 \%$ of patients), growth retardation $(92.3 \%)$, normal intelligence $(88 \%)$, hypocalcaemia/tetany $(85 \%)$, ocular anomalies $(70.8 \%)$, and low parathyroid hormone $(58.3 \%)$, in addition to some dysmorphic facial features and small hands and feet. ${ }^{14}$ The diagnosis of KennyCaffey syndrome in our Bedouin children is unequivocal, since they showed most of the above mentioned traits. Some other features were identified in our patients that have not been reported as a prominent part of the Kenny-Caffey phenotype from other parts of the world. These features included marked IUGR, severly delayed psychomotor development, and microcephaly. Such traits are compatible with recent reports of other Bedouin sibships affected with Kenny-Caffey syndrome. ${ }^{11}$ Apparently, the disease profile in the Middle East differs to some extent from the Kenny-Caffey phenotype described in other parts of the world, which is characterised by the presence of normal intelligence, late closure of the anterior fontanelle with macrocephaly, and postnatal rather than prenatal growth retardation (with adult height ranging between 121 and $149 \mathrm{~cm}) .{ }^{15}$

In cases 1 and 2 of the present report, growth retardation was so severe that their growth parameters were permanently far below the 3rd centile for their age. Impaired growth hormone level does not seem to play any role in the pathogenesis of the disease since it was normal in our cases as well as in some other reported cases in which attempts with growth hormone therapy were unsuccessful. ${ }^{15}{ }^{16}$ Intracranial calcification has been previously reported only once in a postmortem examination of a case with Kenny-Caffey syndrome. ${ }^{17}$ It was also detected in case 1 of the present report and could be one factor responsible for the delayed psychomotor development observed in this case. Intracranial calcification in patients with
Kenny-Caffey syndrome may be age related and this could be the reason why it has not yet been detected in the younger affected brother (case 2).

In our Bedouin patients, we identified a maternally inherited hemizygous microdeletion in the juxtacentromeric region of the long arm of chromosome $22(22 \mathrm{q} 11.2)$ that characterises the CATCH 22 cluster of diseases. Thus, this report includes Kenny-Caffey syndrome as a new member of the rapidly increasing CATCH 22 family and provides a molecular marker for its accurate diagnosis. To that effect, the parental consanguinity in our Bedouin family seems to be coincidental and does not give additional support to the existence of an autosomal recessive form of Kenny-Caffey syndrome. However, this report does not totally exclude the presence of "molecular" heterogeneity of Kenny-Caffey syndrome, analogous to other members of the CATCH 22 family for which a second haploinsuffiency locus on the short arm of chromosome 10 has been suggested. ${ }^{18}$

The report also widens the phenotypic spectrum of CATCH 22 to include some new traits that characterise Kenny-Caffey syndrome, for example, the severe pre/postnatal growth retardation, the cortical thickening/medullary stenosis of the tubular long bones, and the new eye signs described in the introduction of this report. This in turn would give more insight into the corresponding developmental processes and the functional prospects of the recently identified genes at the site of the CATCH 22 microdeletion, particularly the potential candidates for transcription regulation, ${ }^{19}$ chromatin assembly, ${ }^{20}$ embryonic patterning, ${ }^{21}{ }^{22}$ mitochondrial transport, ${ }^{23}$ and adhesion. ${ }^{24}$

1 McKusick VA. Mendelian inheritance in man. 11 th ed. Baltimore: Johns Hopkins University Press, 1994.

2 Scambler PJ, Carey AH, Wyse RK, et al. Microdeletions within $22 \mathrm{q} 11$ associated with sporadic and familial DiGeorge syndrome. Genomics 1991;10:201-6.

3 Scambler PJ, Kelly D, Lindsay E, et al. Velocardiofacial syndrome associated with chromosome 22 deletions encompassing the DiGeorge locus. Lancet 1992;339:1138-9.

4 Lindsay EA, Morris MA, Gos A, et al. Schizophrenia and chromosomal deletions within 22q11.2. Am $\mathcal{F}$ Hum Genet 1995;56:1502-3.

5 Burn J, Takao D, Cross IE, et al. Conotruncal anomaly face syndrome is associated with a deletion within chromosome syndrome is associated with a deletion
$22 \mathrm{q} 11 . \mathcal{F}$ Med Genet 1993;30:822-4.

6 Giannotti A, Digilio MC, Marino B, Mingarella R, Dallapicolla $\mathrm{B}$. Cayler cardiofacial syndrome and chromosome 22q11: part of CATCH 22 phenotype. $A m \mathcal{f}$ Med Genet 1994;53:303-4.

7 Bergada I, Schiffrin A, Sarria A, et al. Kenny syndrome: description of additional abnormalities and molecular studies. Hum Genet 1988;80:39-42.

8 Abdel-Al YK, Auger LT, El-Gharabawi F. Kenny Caffey syndrome. Case report and literature review. Clin Pediatr 1989;28:175-9.

9 Kenny FM, Linarelli L. Dwarfism and cortical thickening, transient hypocalcaemia in a mother and son. $\mathrm{Am} \mathcal{F} \mathrm{Dis}$ Child 1966;111:201-7.

10 Sarria A, Toledo F, Toledo J, et al. Estenosis tubulaire diafisaria (sindrome de Kenny-Caffey): presentaction de cuatro observasiones. An Esp Pediatr 1988;13:373-80.

11 Tahseen $\mathrm{K}$, Khan S, Uma R, et al. Kenny-Caffey syndrome in six Bedouin sipships. Am f Med Genet 1997;69:126-32.

12 Wilson DI, Burn J, Scambler P, Goodship J. DiGeorge syndrome: part of CATCH 22. F Med Genet 1993;30:852-6.

13 Sabry MA, Abulhassan SJ, Abdel Rasool MA, et al. KennyCaffey syndrome is part of the CATCH 22 haploinsufficiency insufficiency spectrum. The 29th annual meeting of the P3.56. Med Genet 1997;9(suppl 2):75. 
14 Franceschini P, Testa A, Bogetti G, et al. Kenny Caffey syndrome in two sibs born to consanguinous parents: evidence for an autosoma

15 Lee WK, Vargas A, Bareness J, Root AW. The Kenny Caffey syndrome: growth retardation and hypocalcaemia in a young boy. Am $\mathcal{F}$ Med Genet 1983;14:773-82.

16 Majewski F, Rosendahl W, Ranke M, Notle K. The Kenny Caffey syndrome, a rare type of growth deficiency with tubular stenosis, transient hypoparathyroidism and anoma136:21-30.

17 Baynton JR, Pheasant TR, Johnson BL, Levin DB, Streeten BW. Occular findings in Kenny Caffey syndrome. Arch Ophthal 1979;97:896-900.

18 Schffenhauer S, Lichtner P, Derakhshandeh-Peykar P, et al. Deletion mapping in patients with partial monosomy $10 \mathrm{p}$ determination of a critical region for DiGeorge and velocardiofacial syndrome. The 29th annual meeting of the European Society of Human Genetics book of abstracts, S01. Med Genet 1997;9(suppl 2):1. 19 Kurahashi $\mathrm{H}$, Akagi $\mathrm{K}$, Inazawa J, et al. Isolation and charHum Mol Genet 1995;4:541-9.
20 Lorain S, Demkzuk S, Lamour V, et al. Structural organisation of the WD repeat protein-encoding gene HIRA in the DiGeorge syndrome critical region of human HIRA in the DiGeorge syndrome critical region
chromosome 22. Genome Res 1996;6:43-50.

21 Pizzuti A, Novelli G, Mari A, et al. Human homologue sequences to the Drosophila dishevelled segment polarity gene are deleted in DiGeorge syndrome. Am 7 Hum Genet 1996;58:722-9.

22 Budarf M, Emanuel B, Driscoll D, Roe B, Gottlieb S. The Di George syndrome minimal critical region contains Goosecoid-like (GSCL) homeobox gene which is expressed early in human development. The 29th annual meeting of the European Society of Human Genetics book of abstracts, S72. Med Genet 1997;9(suppl 2):19.

23 Heisterkamp N, Mulder MP, Langeveld A, et al. Localisation of the human mitochondrial transporter protein gene to chromosome $22 \mathrm{q} 11$ in the DiGeorge syndrome critical region. Genomics 1995;29:451-6.

24 Demczuk S, Aledo R, Zucman J, et al. Cloning of a balanced translocation breakpoint in the DiGeorge syndrome critical region and isolation of a novel adhesion receptor gene. Hum Mol Genet 1995;4:551-8. 